\title{
NOTA EDITORIAL
}

Ao encerrarmos o segundo ano da Revista Direitos Fundamentais \& Justiça, agradecemos a todos cujo auxílio tem sido imprescindível para que a publicação se tornasse, em pouco tempo, um espaço privilegiado para a doutrina jurídica nacional e internacional.

Para este número, no que diz com a doutrina estrangeira, contamos com trabalhos de autores de competência e prestígio notórios e que representam Instituições de Ensino Superior de diferentes países, como é o caso de Rodolfo Arango (Bogotá, Colômbia), Guillermo Escobar (Alcalá, Espanha) e Danilo Zolo (Florença, Itália). Reservamos maior espaço nesse número para a doutrina nacional, mantendo o alto nível dos números anteriores, com os trabalhos da lavra de Rodrigo Brandão (UERJ), Juarez Freitas (PUCRS), Pery Francisco Assis Shikida (UNIOESTE), Lenio Streck (UNISINOS), Maren Taborda (PUCRS), José Maria Tesheiner (PUCRS) e Mariângela Milhoranza.

Nosso Conselho Editorial é, além disso, enriquecido com a adesão do Professor Doutor Juarez Freitas, Professor Titular do Programa de Pós-Graduação em Direito da PUCRS, Professor Adjunto da UFRGS. Damos as boas vindas ao novo Conselheiro, destacando que já estamos publicando artigo de sua lavra sobre o tema da hermenêutica constitucional.

Contamos com a boa acolhida e bom proveito também deste novo número entre a comunidade jurídica, assim como aconteceu com as edições anteriores.

Saudações,

Prof. Dr. Ingo Wolfgang Sarlet 